particularly of the tropical colonies of Belgium. So long ago as 1909, after travelling in South Africa and the Congo, he emphasised the necessity of taking measures without delay for saving a part of the fauna and flora, which intense and often unregulated economic development threatens to destroy. In the Congo in particular, this destruction was going on with great rapidity, often without apparent cause. We owe to the intervention of the King of the Belgians the creation, in 1929, of the Parc National Albert, comprising about 357,000 hectares (nearly 1400 square miles). The administration of this reserve is in the hands of a commission of which the King's son, Prince Leopold, is president, and Prof. V. Van Straelen, director of the Royal Museum of Natural History, Brussels, is vice-president. During last April, King Albert, accompanied by Prof. Van Straelen, visited the Kivu Park in the Belgian Congo, having made the journey specially to see for himself the effectiveness of the measures of protection in force. His gesture for the cause of the protection of the fauna and flora is of high importance and should result in intensification of the efforts being made in this direction, not in the Belgian Congo alone but also in other countries.

\section{Bird Invaders in London}

THE nesting of the jay in Ladbroke Square in west London, recently reported in Cage Birds, is certainly a marked invasion of the metropolitan area by this woodland species, but it has been present in south-east London for years past, and has regularly nested in the grounds of the Horniman Museum at Forest Hill within a few dozen yards of a main road. The curious thing is that it is this shy bird and not the bolder magpie that has colonised London, and that among the typical crows it is the carrion crow and not the building-haunting jackdaw that is the familiar London bird. The colonisation of London by birds of prey is also not in accordance with expectation; the buildings have failed to attract the barn-owl, but the tawny owl is so generally diffused that it has been heard within five minutes' walk of King's Cross Station; while, though the pigeons and ducks in London might have been expected to attract the peregrine falcon, and the sparrows and starlings the sparrow-hawk, the only hawk commonly to be seen is the kestrel, which must subsist there on birds rather than on the mice and insects which are its more usual food.

\section{The Advance of Medicine}

THE Romanes Lecture entitled "The Advance of Medicine" delivered at Oxford on June 1 by Lord Moynihan, president of the Royal College of Surgeons, who received the honorary degree of D.C.L. on that occasion, has been published by the Clarendon Press (2s. 6d. net). After an historical introduction in which he briefly reviews the work of Hippocrates, Galen, Vesalius, the Italian anatomists, Harvey, Morgagni, and John Hunter, Lord Moynihan passes on to Lister, whom he describes as the greatest material benefactor of mankind the world has ever known. He attributes Lister's genius to the fact that he was master both of the Hippocratic method of induction and the Galenic method of deduction, and combined the qualities of a physiologist and clinician. Lord Moynihan deplores the fact that physiology is now losing the close relationship it formerly had with clinical medicine, and urges that physiologists and surgeons should make a common attack upon " the innumerable mysteries of disease ". On the other hand, he maintains that though the aid given by physics, chemistry, and physiology is indispensable, these sciences are merely ancillary to medicine, which is a seience as well as an art in itself. In view of the fact that laboratory aid, though sometimes decisive or at least helpful, is not seldom negligible, the clinician must maintain his sovereignty. In conclusion, Lord Moynihan exemplifies the humanism of medicine by the work of Harvey, John Hunter, Hillman, who discovered anæsthesia, and Lister. Three appendices to the lecture deal respectively with the ideal training of the surgeon, experiments on animals, and the relation of physics and chemistry to medicine.

\section{Modern Oil Production Problems}

Mr. A. Beeby Thompson's recent survey of engineering progress in petroleum production (Institution of Petroleum Technologists, May 10) showed clearly the remarkable changes which modern industrial, chiefly economic, conditions have brought about in the technique of oil mining. Only a few years ago $10,000 \mathrm{ft}$. oil wells and the safe and efficient handling of pressures of $5000 \mathrm{lb}$. were considered impossibilities; unit operation of oilfields, now an accepted principle, was then an unattainable ideal. The modern technique of deep drilling has brought with it a chain of difficult problems confronting oilfield engineers throughout the world. Among these may be mentioned control of flowing wells; freezing of wells as a result of rapid expansion of gas together with formation of ice actually in the well itself ; mechanical extraction of oil, that is, pumping and plant to raise oil to the surface from depths of $5000-10,000 \mathrm{ft}$., involving as it does pump pressures up to several thousand pounds per square inch; crooked holes and their avoidance; air-gas lift efficiency; paraffination of wells where waxy oil is encountered, a difficulty still not satisfactorily solved; the ultimate recovery of oil from at present commercially exhausted pools; disposal of surplus natural gas, particularly in regions far removed from populous areas; and the thorny question of practicability of extending the principle of mining oil measures, as at Pechelbroun. None the less, progress in the last few years has been of such a character that one cannot but anticipate a satisfactory solution to some, if not all, of these problems in the near future, especially when economic conditions in the industry improve.

\section{Street Lighting}

THE improvement in modern street lighting is largely due to the appointment of public lighting engineers whose whole time is devoted to the work. They pay attention to details which have been previously overlooked or neglected. In Electrical Industries for June 15 there is a paper on modern

No. 3269, VoL. 129] 